\title{
COMMENT
}

\section{A new combination coccosphere of the heterococcolith species Coronosphaera mediterranea and the holococcolith species Calyptrolithophora hasleana}

\author{
MARA Y. CORTÉS AND JÖRG BOLLMANN² \\ ${ }^{1}$ Departemento de Geología Marina, Universidad Autónoma de Baja California Sur, Carretera al sur $\mathrm{km} \mathrm{5 \cdot 5,}$ \\ Apdo. Postal 19-B, C.P. 23080 La Paz, B.C.S. Mexico \\ ${ }^{2}$ Geological Institute, ETH Zurich, Sonneggstrasse 5, 8092 Zurich, Switzerland
}

(Received 10 February 2001; accepted 15 October 2001)

This is the first description of a combination coccosphere of the heterococcolithophore species Coronosphaera mediterranea (Lohmann 1902) Gaarder in Gaarder \& Heimdal (1977) and the holococcolithophore species Calyptrolithophora hasleana (Gaarder 1962) Heimdal in Heimdal \& Gaarder (1980) (Figs 1, 2). A single specimen of this new combination coccosphere was found within 53000 analysed cells in one of 189 samples collected at the JGOFS time series station ALOHA, Hawaii, during 1993 to 1996 . The specimen was in a sample collected during autumn 1996 at a water depth of $5 \mathrm{~m}$ at a temperature of $26 \cdot 1^{\circ} \mathrm{C}$, salinity of $35.0 \mathrm{psu}$, phosphate of $0.002 \mu \mathrm{mol} / \mathrm{kg}$ and in nitrate-depleted water (for details see Cortés, 1998; Cortés et al., 2001).

A combination coccosphere composed of heterococcoliths of Coronosphaera mediterranea and holococcoliths of Calyptrolithina wettsteinii (Kamptner 1937) Norris (1985) has been reported by Kamptner (1941) and recently confirmed by Cros et al. (2000) from the Mediterranean Sea. During the studied time period at the ALOHA time series station these two species accounted for $<1 \%$ of the nanoplankton assemblage. No coccospheres composed entirely of $C$. wettsteinii were found in samples which contained $C$. mediterranea and/or $C$. hasleana.

The combination of Coronosphaera mediterranea with Calyptrolithophora hasleana and Coronosphaera mediterranea with Calyptrolithina

Correspondence to: M. Y. Cortés. Tel. +52 1 1280440. Fax + 52 1 120801.e-mail: mycortes@uabcs.mx wettsteinii implies that these three taxa belong to the same species. They may represent different stages in a complex life cycle of the same species as already suggested for other taxa (Kleijne, 1991; Cros et al., 2000).

The name Coronosphaera mediterranea has priority and is therefore the appropriate name. In addition, Cros et al. (2000) have suggested a revision of the nomenclatural taxonomy of hetero- and

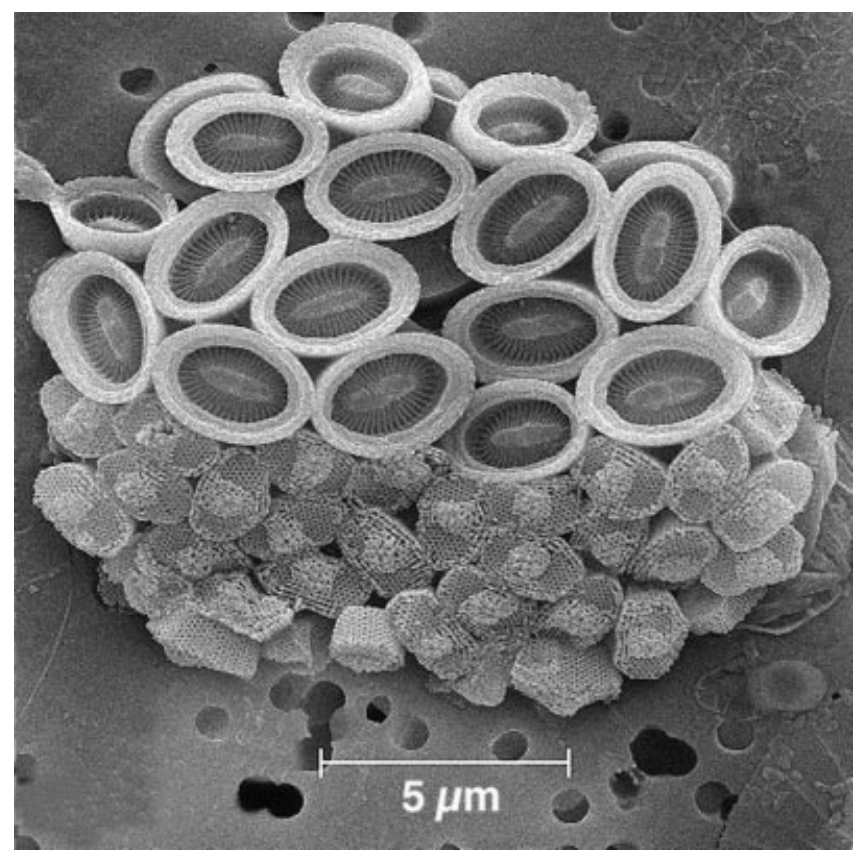

Fig. 1. Coccosphere of Coronosphaera mediterranea with Calyptrolithophora hasleana. (Taken with a Philips XL30 scanning electron microscope at the Geological Institute of the ETH Zurich.) 


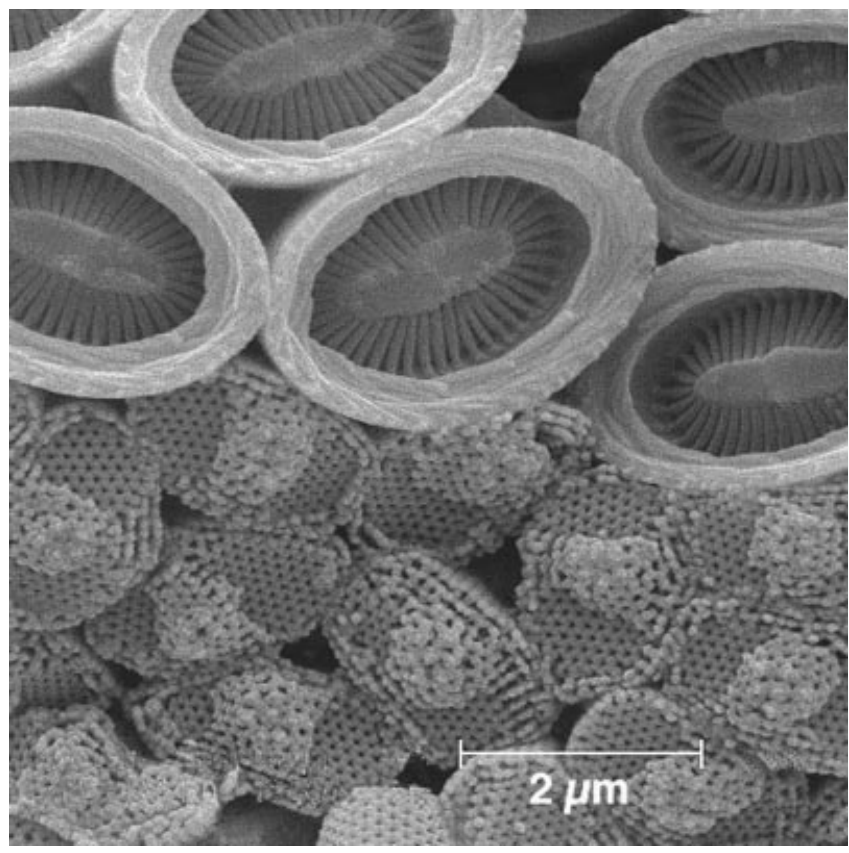

Fig. 2. Detail of the same coccosphere as shown in Fig. 1. (Taken with a Philips XL30 scanning electron microscope at the Geological Institute of the ETH Zurich.)

holococcolith associations. According to their proposal, we suggest the following names for the heterococcolith-bearing and the two holococcolithbearing phases of this species: Coronosphaera mediterranea (Lohmann 1902) Gaarder in Gaarder \& Heimdal (1977), Coronosphaera mediterranea $\mathrm{HO}$ wettsteinii and Coronosphaera mediterranea $\mathrm{HO}$ hasleana.

\section{Acknowledgements}

We are grateful to Annelies Kleijne for her valuable comments. This work is a contribution to the ECTMR CODENET program (EC contract no. ERBFRMX-CT97-0113) and was funded by the Swiss Federal Office for Education (BBW-no. 97-0412).

\section{References}

Cortés, M., Bollmann, J. \& Thierstein, H. R. (2001). Coccolithophore ecology at the HOT station ALOHA, Hawaii. DeepSea Res. II., 48: 1957-1981.

CORTÉs, M. (1998). Coccolithophores at the time-series station ALOHA, Hawaii: population dynamics and ecology. Unpublished $\mathrm{PhD}$ dissertation, University of Zurich. 176pp.

Cros, L., Kleijne, A., Zeltner, A., Billard, C. \& Young, J. (2000). New examples of holococcolith-heterococcolith combination coccospheres and their implication for coccolithophorid biology. Mar. Micropaleontol., 39: 1-34.

GAARDER, K. R. (1962). Electron microscope studies on holococcolithophorids. Nytt. Mag. Bot., 10: 35-51.

GAARDER, K. R. \& Heimdal, B. R. (1977). A revision of the genus Syracosphaera Lohmann (Coccolithineae). Meteor Forschungsergebnisse, Ser. D., 24: 54-71.

Heimdal, B. R. \& GAARDER, K. R. (1980). Coccolithophorids from the northern part of the eastern central Atlantic. I. Holococcolithophorids. Meteor Forschungsergebnisse, Ser. D., 32: 1-14.

Kamptner, E. (1937). Neue und bemerkenswerte Coccolithineen aus dem Mittelmeer. Arch. Protistenkd., 89: 219-316.

KAMPTNER, E. (1941). Die Coccolithineen der Südwestküste von Istrien. Ann. Naturhist. Mus. Wien., 51: 54-149.

Kleijne, A. (1991). Holococcolithophores from the Indian Ocean, Red Sea, Mediterranean Sea and North Atlantic Ocean. Mar. Micropaleontol., 17: 1-76.

Lohmann, H. (1902). Die Coccolithophoridae. Arch. Protistenkd., 1: 89-165.

NoRris, R. E. (1985). Indian Ocean nanoplankton. II. Holococcolithophorids (Calyptrosphaeraceae, Prymnesiophyceae) with a review of extant genera. J. Phycol., 21: 619-641. 